\title{
Clinicopathological and Molecular Factors, Risk Factors, Treatment Outcomes and Risk of Recurrence in Mesenteric and Retroperitoneal Extragastrointestinal Stromal Tumors
}

\author{
KONSTANTINOS G. APOSTOLOU ${ }^{1}$, DIMITRIOS SCHIZAS ${ }^{1}$, ELENI VAVOURAKI ${ }^{2}$, \\ ADAMANTIOS MICHALINOS ${ }^{1}$, DIAMANTIS I. TSILIMIGRAS ${ }^{1}$, NIKOLAOS GARMPIS ${ }^{3}$, \\ CHRISTOS DAMASKOS ${ }^{3,4}$, ALEXANDROS PAPALAMPROS $^{1}$ and THEODORE LIAKAKOS ${ }^{1}$ \\ ${ }^{1}$ First Department of Surgery, and ${ }^{3}$ Second Department of Propedeutic Surgery, \\ Laikon General Hospital, National and Kapodistrian, University of Athens, Athens, Greece; \\ ${ }^{2}$ Nephrology Unit, Alexandra General Hospital of Athens, Athens, Greece; \\ ${ }^{4}$ N.S. Christeas Laboratory of Experimental Surgery and Surgical Research, Medical School, \\ National and Kapodistrian University of Athens, Athens, Greece
}

\begin{abstract}
Background/Aim: The objective of the present study was to determine the clinicopathological factors and treatment outcomes of patients suffering from mesenteric or retroperitoneal extragastrointestinal stromal tumors (EGISTs). Materials and Methods: A detailed search in PubMed, using the key words "extragastrointestinal stromal tumors" and "EGIST", found eight studies fulfilling the criteria of this study. Results: Thirty-six patients with a mesenteric and 24 patients with a retroperitoneal EGIST were analyzed, with a follow-up period ranging from 2 to 192 months. Retroperitoneal tumors presented as larger tumors than mesenteric ones, with $95 \%$ and 93\% immunohistochemical positivity for CD117 antigen, respectively. Surgical resection was performed in $91 \%$ of cases, with $57 \%$ of patients with mesenteric and $70 \%$ of patients with retroperitoneal EGISTs being alive at the last follow-up. Conclusion: EGISTs most commonly are of considerable size and usually with a high mitotic count, rendering them high-risk tumors. Tumor necrosis, nuclear atypia, tumor histology, and mutations in the tyrosine kinase KIT or platelet-derived growth factor receptor A (PDGFRA) gene, seem to influence tumor behavior.
\end{abstract}

Correspondence to: Dr. Konstantinos G. Apostolou MD, M.Sc., Ph.D., 1st Department of Surgery, Laikon General Hospital, National and Kapodistrian University of Athens, 17 Agiou Thoma Street, Athens, 11527, Athens, Greece. Mobile: +30 6940167070, e-mail: konstantinos.apostolou@gmail.com

Key Words: Extragastrointestinal, stromal, mesentery, retroperitoneum, KIT, review.
Gastrointestinal stromal tumors (GISTs) are the most frequent mesenchymal tumors of the gastrointestinal (GI) tract (1). They may arise from any part of the digestive tract, with the stomach and the small intestine being the most common sites (2). GISTs are thought to originate from, or to show differentiation toward, the interstitial cells of Cajal, which are the pacemaker cells present in the GI tract. Their diagnosis is based on histomorphological, as well as immunohistochemical features, and in the majority of cases, on histochemical immunopositivity for the tyrosine kinase receptor of KIT (CD117) (3-5).

Recent studies have demonstrated that mesenchymal tumors with clinicopathological and molecular profiles resembling GISTs (6) may arise outside the GI tract, especially in soft tissues of the abdomen and the retroperitoneum $(1,7)$. These tumors are called extragastrointestinal stromal tumors (EGISTs) and account for $<10 \%$ of all stromal tumors. Most EGISTs arise from the mesentery, the retroperitoneum, and the omentum as well as other abdominal sites.

Although most EGISTs are described as malignant tumors, due to their rarity little is known about their incidence, pathogenesis, genetic profile and prognosis. Moreover, even nowadays, their malignant potential is determined by the same parameters used for their GI counterparts, but it still remains unclear whether this is a rational approach.

In the present study, we aimed to review the clinicopathological, immunohistochemical and genetic alterations that are present in EGISTs of the mesentery and retroperitoneum, that are two of the most common sites of EGIST localization. 


\section{Materials and Methods}

A detailed search in PubMed for citations that included EGISTs, using the key words "extragastrointestinal stromal tumors" and "EGIST" revealed over 200 studies. Prospective and retrospective series reporting on EGIST of the mesentery or the retroperitoneum were included if they reported defined and not mixed data regarding each tumor localization. Case reports, as well as sub-studies of larger series by the same group, were not included in our analysis, in order to avoid duplication of data. After an initial review of these studies, only eight reports seemed to match our criteria (Figure 1) and a review of these reports was conducted and the full text was reviewed.

Statistical analyses were performed only on the data extracted from the selected studies. Basic descriptive statistics (simple counts and means) were used to summarize the patient and study data.

\section{Results}

Study characteristics. A total of eight retrospective studies (2, 8-14) were extracted for the present review. Six out of these eight studies $(2,8-10,13,14)$ were from a single institution (Table I). Six out of eight studies originated from Asia (9-14), one study originated in the USA (2), while the remaining study originated from Europe (8). All studies reported on the localization of EGISTs, as well as on the immunohistochemical results of the CD117 or CD34 antigens, while three studies (10-12) reported on the results of mutation testing for CD117 or platelet-derived growth factor receptor A (PDGFRA) mutations (Tables II and III).

The follow-up rate regarding the patients with a mesenteric or a retroperitoneal EGIST was reported in all eight studies and ranged from $43 \%$ to $100 \%$, with a followup period ranging from 2 to 192 months (Table I).

Patient characteristics. The total number of patients enrolled in these studies was 60 . All studies reported on the patient gender and $57 \%$ of the patients were women. The mean patient age was 54 years (Table II).

Out of 60 patients, 36 presented with a mesenteric EGIST, while the remaining 24 patients suffered from a retroperitoneal EGIST. Even at the time of diagnosis, none of the patients presented specific symptoms, but rather had unexplained symptoms, such as vague abdominal pain, loss of appetite, as well as nausea or vomiting. Four studies reported on the presentation status of the patients, and $88 \%$ of patients presented with localized disease, while the remaining $12 \%$ already had metastases at the time of diagnosis (four studies, $\mathrm{n}=34$ patients). No patient received any kind of neo-adjuvant treatment, while $31 \%$ of patients received adjuvant treatment following surgical resection (four studies, $\mathrm{n}=26$ patients) (Table II).

Tumor characteristics. Mean tumor size in its maximum diameter was reported in all studies, and ranged from 11.7 to $19 \mathrm{~cm}$, with a mean value of $14.2 \mathrm{~cm}$. Retroperitoneal tumors presented as larger tumors than mesenteric ones, with a mean size of $17 \mathrm{~cm}$ versus $12.5 \mathrm{~cm}$, respectively (Table III). The vast majority of these tumors were immunohistochemically positive for CD117 antigen (93\% of mesenteric and $95 \%$ of retroperitoneal tumors). Three studies reported on the expression of the CD34 antigen, which was demonstrated in $80 \%$ of the mesenteric tumors, while it was not observed in any retroperitoneal tumor (Table III). Three out of eight studies reported on mutation testing for the detection of tumor mutations in the tyrosine kinase $K I T$ or PDGFRA gene. Mutation testing revealed that $22 \%$ and $33 \%$ of mesenteric EGISTSs demonstrated mutations in the KIT and PDGFRA gene, respectively, compared with $60 \%$ and $10 \%$, respectively, of the retroperitoneal EGISTs (Table III).

Mean tumor mitotic count was 14/50 high-power fields (HPF) (five studies) and 12/50 HPF (six studies) for the mesenteric and retroperitoneal EGISTs, respectively. Tumor histology was reported in all studies, demonstrating $70 \%$ spindle, $17 \%$ epithelioid and $13 \%$ mixed morphology in mesenteric tumors, whereas $46 \%$ of retroperitoneal EGISTs were of spindle, $25 \%$ of epithelioid and $26 \%$ of mixed morphology (Table III).

Tumor risk, classified according to Fletcher's criteria (3), was reported in all studies. Mesenteric EGISTs were classified as low-risk in $17 \%$, intermediate-risk in $5 \%$ and high-risk in $78 \%$, whereas $17 \%$ of retroperitoneal EGISTs were classified as intermediate-risk and $83 \%$ as high-risk (Table III). Tumor necrosis was demonstrated as a predictor of survival of patients with EGISTs in two studies $(2,12)$, followed by the presence of obvious nuclear atypia, as a negative predictor of outcome (12).

Surgical resection of the EGISTs was performed in $91 \%$ of the total cases (seven studies), with an R0 resection achieved in $37.5 \%$ of cases (one study). Twenty-seven percent of patients developed metastases during the followup period (four studies) (Table II), with $57 \%$ of patients with mesenteric (six studies) and $70 \%$ of patients with retroperitoneal EGISTs (seven studies) being alive at the last follow-up. Median survival was reported in one study and was 34 months, ranging from 7 to 148 months. Tumor recurrence occurred in $21 \%$ of patients with mesenteric EGISTs (five studies) and $36 \%$ of patients with retroperitoneal EGISTs (six studies) during the follow-up period (Table III).

\section{Discussion}

EGISTs are reported to be more common in females than males $(2,13,15)$, a finding also supported by the present study. They most commonly present as enlarged intraabdominal or retroperitoneal masses, which often cause no specific symptoms, but rather unexplained vague abdominal 


\section{Flowchart}

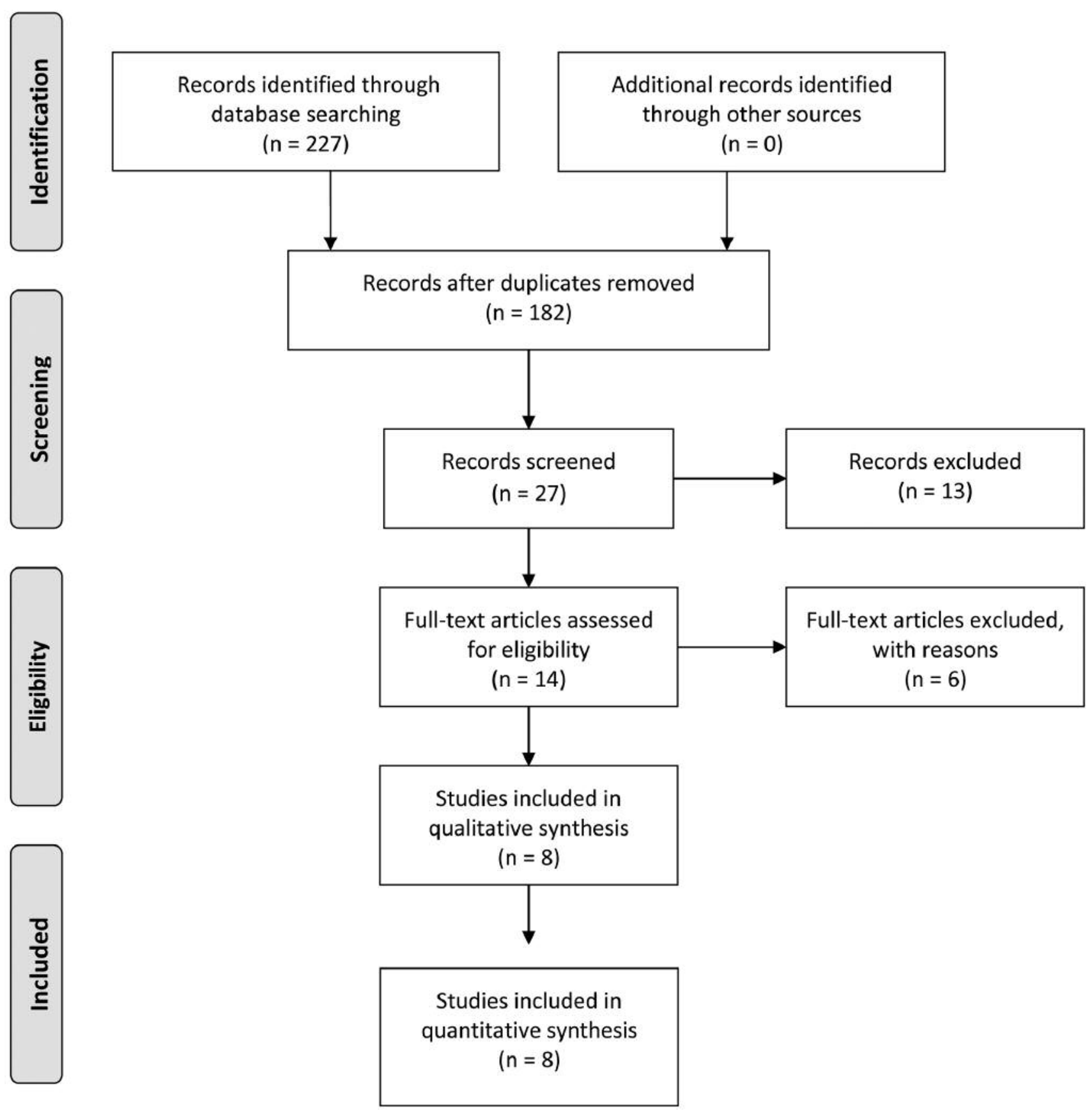

Figure 1. Scheme representing how review of the literature was conducted.

pain, as well as loss of appetite, nausea or vomiting. They are most often discovered on physical examination as palpable abdominal masses $(2,9)$, with the contrast-enhanced computed tomography (CT) being the modality of choice in the imaging algorithm of GISTs (16).
The recognition of the critical role of activating KIT mutations in the pathogenesis of GISTs (17-19), which leads to the expression of the KIT protein (CD117), has led to the recognition of a reliable immunophenotypic marker for these neoplasms. However, recent studies have demonstrated that 
Table I. Characteristics of included studies.

\begin{tabular}{|c|c|c|c|}
\hline Author (Ref) & Type of study & Institutional type & Follow-up rate (months) \\
\hline Reith et al. 2000 (2) & Retrospective & Single & $100 \%(5-67)$ \\
\hline Llenas et al. 2008 (8) & Retrospective & Single & $67 \%(11-77)$ \\
\hline Goh et al. 2009 (9) & Retrospective & Single & $100 \%(27-42)$ \\
\hline Yamamoto et al. 2011 (10) & Retrospective & Single & $100 \%(5-192)$ \\
\hline Zheng et al. 2011 (11) & Retrospective & Multi & $93 \%(45)$ \\
\hline Kim et al. 2012 (12) & Retrospective & Multi & $100 \%(17-153)$ \\
\hline Patnayak et al. 2013 (13) & Retrospective & Single & $43 \%(2-12)$ \\
\hline Iqbal et al. 2015 (14) & Retrospective & Single & $100 \%(28-148)$ \\
\hline \multirow[t]{2}{*}{ Summary } & $100 \%$ Retrospective & Single, $N=6$ & Mesenteric: 5-192 months \\
\hline & & Multi, $N=2$ & Retroperitoneal: 2-140 months \\
\hline
\end{tabular}

Table II. Characteristics of patients in the included studies.

\begin{tabular}{|c|c|c|c|c|c|c|c|c|c|}
\hline Author (Ref) & $\begin{array}{c}\text { No. } \\
\text { of } \\
\text { patients }\end{array}$ & $\begin{array}{l}\text { Mean } \\
\text { patient } \\
\text { age, } \\
\text { years }\end{array}$ & $\begin{array}{c}\text { Male/ } \\
\text { female, } \\
\%\end{array}$ & $\begin{array}{c}\text { Localization } \\
\text { of } \\
\text { EGIST, } \\
\mathrm{N}\end{array}$ & $\begin{array}{c}\text { Status } \\
\text { at } \\
\text { presentation }\end{array}$ & $\begin{array}{c}\text { Neoadjuvant/ } \\
\text { adjuvant } \\
\text { treatment } \\
(\%)\end{array}$ & $\begin{array}{c}\text { Metastasis, } \\
\% \\
\text { N }(\%)\end{array}$ & $\begin{array}{l}\text { Alive } \\
\text { at the } \\
\text { last } \\
\text { follow-up, }\end{array}$ & $\begin{array}{c}\text { Median } \\
\text { survival } \\
\text { (range) } \\
\text { months }\end{array}$ \\
\hline Reith et al. 2000 (2) & 6 & 54 & $17 / 83$ & Retroperitoneum: 6 & - & - & - & $5(83 \%)$ & - \\
\hline Llenas et al. 2008 (8) & 3 & 63 & $67 / 33$ & Mesentery: 3 & Localized: 3 & Adjuvant: $33 \%$ & $0 \%$ & $1(50 \%)$ & - \\
\hline $\begin{array}{l}\text { Goh et al. } 2009 \\
\text { (9) }\end{array}$ & 2 & 52 & $50 / 50$ & $\begin{array}{c}\text { Mesentery: } 1 \\
\text { Retroperitoneum: } 1\end{array}$ & - & - & - & $2(100 \%)$ & - \\
\hline $\begin{array}{l}\text { Yamamoto et al. } 2011 \\
\text { (10) }\end{array}$ & 3 & 65 & $0 / 100$ & $\begin{array}{c}\text { Mesentery: } 2 \\
\text { Retroperitoneum: } 1\end{array}$ & Localized & $0 \%$ & $0 \%$ & $2(67 \%)$ & - \\
\hline $\begin{array}{l}\text { Zheng et al. } 2011 \\
\text { (11) }\end{array}$ & 15 & 59 & $60 / 40$ & $\begin{array}{c}\text { Mesentery: } 9 \\
\text { Retroperitoneum: } 6\end{array}$ & Localized & - & - & $8(53 \%)$ & - \\
\hline $\begin{array}{l}\text { Kim et al. } 2012 \\
\text { (12) }\end{array}$ & 11 & 53 & $55 / 45$ & $\begin{array}{c}\text { Mesentery: } 8 \\
\text { Retroperitoneum: } 3\end{array}$ & - & - & $36 \%$ & $6(55 \%)$ & - \\
\hline $\begin{array}{l}\text { Patnayak et al. } 2013 \\
\text { (13) }\end{array}$ & 7 & 54 & $28.5 / 71.5$ & $\begin{array}{c}\text { Mesentery: } 3 \\
\text { Retroperitoneum: } 4\end{array}$ & $\begin{array}{c}\text { - } \\
\text { Localized: } 9\end{array}$ & $\begin{array}{l}\text { Adjuvant: } 28.5 \% \\
\text { Adjuvant: } 38.5 \%\end{array}$ & $\begin{array}{c}- \\
31 \%\end{array}$ & $\begin{array}{c}3(100 \%) \\
7(54 \%)\end{array}$ & $34(7-148$ \\
\hline $\begin{array}{l}\text { Iqbal et al. } 2015 \\
\text { (14) }\end{array}$ & 13 & 46 & $38 / 62$ & $\begin{array}{c}\text { Mesentery: } 10 \\
\text { Retroperitoneum: } 3\end{array}$ & Metastatic: 4 & & & & \\
\hline Summary & $\begin{array}{c}\mathrm{N}=60 \\
(8 \\
\text { studies })\end{array}$ & $\begin{array}{c}54 \\
(8 \\
\text { studies })\end{array}$ & $\begin{array}{c}43 / 57 \% \\
\quad(8 \\
\text { studies })\end{array}$ & $\begin{array}{c}\text { Mesentery: } 36 \\
\text { Retroperitoneum: } \\
24 \text { (8 studies) }\end{array}$ & $\begin{array}{l}\text { Localized: } 30 \\
\text { Metastatic: } \\
4 \text { (4 studies) }\end{array}$ & $\begin{array}{c}\text { Adjuvant: } 31 \% \\
\text { Neoadjuvant: } 0 \% \\
\text { (4 studies) }\end{array}$ & $\begin{array}{c}27 \% \\
\text { (4 studies) }\end{array}$ & $\begin{array}{c}\text { Mesenteric: } \\
57 \% \\
\text { (6 studies) } \\
\text { Retroperitoneal: } \\
70 \% \\
\text { (7 studies) }\end{array}$ & $\begin{array}{c}34 \\
\text { months } \\
(1 \text { study }) \\
\text { l: }\end{array}$ \\
\hline
\end{tabular}

a minor proportion of GISTs, accounting for $3 \%$ to $5 \%$ of all GIST cases, are immunohistochemically negative for CD117 (20). Moreover, other studies have underlined the significance of CD34 as a more reproducible marker of GISTs (21). However, it has become evident in recent years that CD34 is expressed in no more than $60 \%$ to $70 \%$ of GISTs, as well as that other neoplasms, such as the smoothmuscle tumors may exhibit a CD34 immunopositivity. Given the histological and immunophenotypic similarity of EGISTs to their GI tract counterparts, the findings of the present study are in agreement with the aforementioned data, recognizing the critical role of CD117 in the diagnosis of EGISTs, as well as the supplementary role of CD34 expression for the diagnosis of these lesions.

The evolution of molecular biology and the recognition that GISTs frequently harbor a gain-of-function mutation of the KIT gene or PDGFRA gene (22-24) has shed light on the correct classification of some soft-tissue tumors as GISTs, as well as on their prognosis. KIT exon 11 mutation is the most common type, and is present in approximately $70 \%$ of GISTs, with a small proportion of GISTs (5\% to $10 \%$ ) harboring a mutation in the PDGFRA exon 12 or 18 . Given the histological and 
Table III. Tumor characteristics.

\begin{tabular}{|c|c|c|c|c|c|c|c|c|c|c|}
\hline $\begin{array}{l}\text { Author } \\
\text { (Ref) }\end{array}$ & $\begin{array}{c}\text { Mean max } \\
\text { tumor } \\
\text { diameter, } \\
\mathrm{cm}\end{array}$ & $\begin{array}{l}\text { CD117- } \\
\text { positive, } \\
\%\end{array}$ & $\begin{array}{c}\text { CD34- } \\
\text { positive, } \\
\%\end{array}$ & $\begin{array}{c}K I T / \\
\text { PDGFRA } \\
\text { mutation }\end{array}$ & $\begin{array}{l}\text { Histological } \\
\text { morphology }\end{array}$ & $\begin{array}{c}\text { Mean } \\
\text { mitotic } \\
\text { count, /50 } \\
\text { HPF }\end{array}$ & $\begin{array}{l}\text { Tumor } \\
\text { risk, } \\
\%\end{array}$ & $\begin{array}{c}\text { Surgical } \\
\text { resection, } \\
\%\end{array}$ & $\begin{array}{c}\text { R0 } \\
\text { Surgical } \\
\text { resection, } \\
\%\end{array}$ & $\begin{array}{l}\text { Recurrence } \\
\text { rate, } \\
\%\end{array}$ \\
\hline $\begin{array}{l}\text { Reith et al. } \\
2000 \text { (2) }\end{array}$ & 19 & $100 \%$ & - & - & $\begin{array}{c}\text { Spindle: } 33 \% \\
\text { Epithelioid: } 67 \%\end{array}$ & 9 & $\begin{array}{l}\text { IR: } 17 \% \\
\text { HR: } 83 \%\end{array}$ & - & - & - \\
\hline $\begin{array}{l}\text { Llenas et al. } \\
2008(8)\end{array}$ & 13 & $100 \%$ & $67 \%$ & - & Spindle: $100 \%$ & - & HR: $100 \%$ & $100 \%$ & - & $67 \%$ \\
\hline $\begin{array}{l}\text { Goh et al. } \\
2009 \text { (9) }\end{array}$ & 18 & $100 \%$ & - & - & $\begin{array}{c}\text { Spindle: } 50 \% \\
\text { Mixed: } 50 \%\end{array}$ & $>10$ & HR: $100 \%$ & $100 \%$ & - & $50 \%$ \\
\hline $\begin{array}{l}\text { Yamamoto et al. } \\
2011 \text { (10) }\end{array}$ & 12 & $0 \%$ & $67 \%$ & $\begin{array}{c}\text { KIT: } 33 \% \\
\text { PDGFRA: } \\
33 \%\end{array}$ & $\begin{array}{c}\text { Epithelioid: } 67 \% \\
\text { Mixed: } 33 \%\end{array}$ & 3 & $\begin{array}{c}\text { LR: } 33 \% \\
\text { IR: } 33 \% \\
\text { HR: } 33 \%\end{array}$ & $100 \%$ & - & $0 \%$ \\
\hline $\begin{array}{l}\text { Zheng et al. } \\
2011 \text { (11) }\end{array}$ & 14.5 & $100 \%$ & - & $\begin{array}{c}\text { KIT: } 40 \% \\
\text { PDGFRA: } \\
13 \%\end{array}$ & $\begin{array}{c}\text { Spindle: } 53 \% \\
\text { Epithelioid: } 27 \% \\
\text { Mixed: } 20 \%\end{array}$ & 6 & $\begin{array}{c}\text { LR: } 47 \% \\
\text { IR: } 40 \% \\
\text { HR: } 13 \%\end{array}$ & $100 \%$ & - & - \\
\hline $\begin{array}{l}\text { Kim et al. } \\
2012(12)\end{array}$ & 14.5 & - & - & $\begin{array}{c}\text { KIT: } 18 \% \\
\text { PDGFRA: } \\
27 \% \\
\text { KIT \& } \\
\text { PDGFRA: } \\
9 \%\end{array}$ & $\begin{array}{c}\text { Spindle: } 45 \% \\
\text { Epithelioid: } 18 \% \\
\text { Mixed: } 37 \%\end{array}$ & 27 & $\begin{array}{l}\text { LR: } 18 \% \\
\text { HR: } 82 \%\end{array}$ & $100 \%$ & - & $9 \%$ \\
\hline $\begin{array}{l}\text { Patnayak et al. } \\
2013(13)\end{array}$ & 14.4 & $100 \%$ & - & - & $\begin{array}{l}\text { Spindle: } 71.5 \% \\
\text { Mixed: } 28.5 \%\end{array}$ & 11 & $\begin{array}{l}\text { HR: } 86 \% \\
\text { LR: } 14 \%\end{array}$ & $100 \%$ & - & $28.5 \%$ \\
\hline $\begin{array}{l}\text { Iqbal et al. } \\
2015 \text { (14) }\end{array}$ & 11.7 & $100 \%$ & $38 \%$ & - & $\begin{array}{c}\text { Spindle: } 93 \% \\
\text { Mixed: } 7 \%\end{array}$ & 27 & $\begin{array}{l}\text { HR: } 85 \% \\
\text { LR: } 15 \%\end{array}$ & $61.5 \%$ & $37.5 \%$ & $33 \%$ \\
\hline Summary & $\begin{array}{c}14.2 \mathrm{~cm} \\
\text { Mesenteric: } \\
12.5 \mathrm{~cm} \\
\text { Retro- } \\
\text { peritoneal: } \\
17 \mathrm{~cm} \\
\text { (8 studies) }\end{array}$ & $\begin{array}{c}\text { Mesenteric: } \\
93 \% \\
\text { (7 studies) } \\
\text { Retro- } \\
\text { peritoneal: } \\
95 \% \\
\text { (7 studies) }\end{array}$ & $\begin{array}{c}\text { Mesenteric: } \\
80 \% \\
\text { (2 studies) } \\
\text { Retro- } \\
\text { peritoneal: } \\
0 \% \\
\text { (1 study) }\end{array}$ & $\begin{array}{c}\text { Mesenteric: } \\
\text { KIT: } 22 \% \\
\text { PDGFRA: } \\
33 \% \\
\text { Retro- } \\
\text { peritoneal: } \\
\text { KIT: } 60 \% \\
\text { PDGFRA: } \\
10 \%\end{array}$ & $\begin{array}{c}\text { Mesenteric: } 70 \% \\
\text { spindle, } 17 \% \\
\text { epithelioid, } \\
13 \% \text { mixed } \\
\text { Retro- } \\
\text { peritoneal: } \\
46 \% \text { spindle, } \\
25 \% \text { epithelioid, } \\
26 \% \text { mixed }\end{array}$ & $\begin{array}{c}\text { Mesenteric: } \\
14 \\
\text { (5 studies) } \\
\text { Retro- } \\
\text { peritoneal: } \\
12 \\
\text { (6 studies) }\end{array}$ & $\begin{array}{c}\text { Mesenteric: } \\
17 \% \text { LR } \\
5 \% \mathrm{IR} \\
78 \% \mathrm{HR} \\
\text { Retro- } \\
\text { peritoneal: } \\
0 \% \mathrm{LR} \\
17 \% \mathrm{IR} \\
83 \% \mathrm{HR}\end{array}$ & $\begin{array}{c}91 \% \\
(7 \\
\text { studies })\end{array}$ & $\begin{array}{l}37.5 \% \\
(1 \\
\text { study })\end{array}$ & $\begin{array}{c}\text { Mesenteric: } \\
21 \% \\
\text { (5 studies) } \\
\text { Retro- } \\
\text { peritoneal: } \\
36 \% \\
\text { (6 studies) }\end{array}$ \\
\hline
\end{tabular}

PDGFRA: Platelet-derived growth factor receptor A; HPF: high-power fields; R0: surgical resection with macroscopic and microscopic negative resection margins; IR: intermediate risk; HR: high risk; LR: low risk.

immunophenotypic similarity of EGISTs to their GI tract counterparts, it becomes evident that mutation testing is also helpful in the correct diagnosis and definition of prognosis of EGISTs. The results of the present study revealed that the majority of the retroperitoneal EGISTs showed a trend towards harboring KIT mutations, with a small subset of them presenting as PDGFRA mutant, while on the other hand, mesenteric EGISTs showed a trend towards harboring PDGFRA mutations more frequently than KIT mutations.

The immunophenotypic and molecular characteristics of EGISTs and GISTs have also been correlated with their histological subtype, with CD117-positive EGISTs being more frequently of spindle rather than epithelioid cell morphology and harboring KIT mutations, whereas CD117negative EGISTs are rather of epithelioid cell morphology, as well as PDGFRA mutant (20). This fact was not demonstrated in the present study, in which despite the differences between the mesenteric and retroperitoneal EGISTs regarding the underlying mutations, the spindle cell morphology was the most frequent, followed by the epithelioid, rendering the mixed morphology as the least frequent. The clarification of the presence or not of KIT or PDGFRA mutations in GISTs and EGISTs is extremely important for the definition of their prognosis as well as their response to neoadjuvant or adjuvant treatment with the tyrosine kinase inhibitor imatinib (Gleevec, Glivec; Novartis Pharma AG, Basel, Switzerland). As not only KIT-mutant EGISTs and GISTs, but also more than one-third of PDGFRA-mutant tumors may respond to imatinib (25), mutation screening may be helpful in these tumors. 
Due to the fact that EGISTs are rare tumors, there are few reports to date about the associations between prognostic factors and outcomes of EGISTs $(1,2,15,26)$. EGISTs develop exclusively outside the GI tract, practically in any part of the abdomen and retroperitoneum, thus may grow in size considerably before the onset of symptoms. On the other hand, the gold standard approach for the definition of risk of aggressive behavior of GISTs depends on the evaluation of tumor size as well as its mitotic count (3). The present study demonstrated that the majority of mesenteric and retroperitoneal EGISTs were larger than $10 \mathrm{~cm}$ in their maximal diameter, with the retroperitoneal tumors being larger than the mesenteric ones. Despite the lack of a standard approach for the definition of risk of EGISTs to date, due to their sparsity, if the evaluation of their risk of recurrence, local or distant, is based on the respective system for GISTs (3), this renders the majority of them as high-risk tumors, based on their size alone. This fact was also demonstrated in the present study, in which $>75 \%$ of EGISTs were classified as high-risk tumors, with retroperitoneal tumors showing a stronger trend towards this feature, a fact which in part explains the more aggressive course of EGISTs compared with small intestinal GISTs. This aspect should be evaluated in patients, considering that routine gastrointestinal endoscopies are more often performed, compared with routine abdominal imaging, with the use of ultrasound and, in particular, computed tomographic scans, which makes EGISTs more likely to be discovered at a greater size compared with GISTs, and, therefore, to have a more aggressive behavior.

Apart from the primary role of tumor size, the tumor mitotic count also seems to be an independent predictor of aggressive tumor behavior. The majority of the mesenteric and retroperitoneal EGISTs of the present study demonstrated a mitotic count $>10 / 50 \mathrm{HPF}$, which based on the respective system for the definition of risk of an aggressive behavior of GISTs (3) renders the majority of them as high-risk tumors. Thus, it becomes evident that the vast majority of EGISTs are classified as high-risk tumors, based not only on their great size but on their high mitotic count, as also described by other studies $(2,11,12)$.

Other parameters may also affect tumor behavior and risk of recurrence. Tumor necrosis was demonstrated as a predictor of survival of patients with EGISTs in two studies $(2,12)$, followed by the presence of obvious nuclear atypia, as a negative predictor of outcome (12). Tumor histology is still a controversial factor, since it has been implicated both as a negative predictor of outcome (12) and as not being one (2). However, in the era of molecular biology and medicine, and with the evolution of gene mutation testing, other factors, especially at the molecular level, may influence tumor behavior, such as the CD117-negative GISTs harboring mutations in the PDGFRA gene, with a favorable prognosis compared to their CD117-positive counterparts, and necessitate further investigation.

\section{Conclusion}

In summary, EGISTs are rare tumors arising exclusively outside the GI tract, with histological and immunophenotypic characteristics similar to those of GISTs, accounting for $<10 \%$ of the stromal tumors. Mesenteric and retroperitoneal EGISTs most commonly are of spindle cell morphology, of considerable size and usually with a high mitotic count, rendering them as high-risk tumors. Moreover, tumor necrosis, obvious nuclear atypia, tumor histology, as well as mutations in the KIT or PDGFRA gene seem to influence tumor behavior, rendering mutation testing necessary for the complete characterization of these neoplasms. However, due to their sparsity, future studies with a larger number of patients will definitely shed light on this category of neoplasms.

\section{References}

1 Yamamoto H, Oda Y, Kawaguchi K, Nakamura N, Takahira T, Tamiya S, Saito T, Oshiro Y, Ohta M, Yao T and Tsuneyoshi M: $c$-KIT and PDGFRA mutations in extragastrointestinal stromal tumor (gastrointestinal stromal tumor of the soft tissue). Am J Surg Pathol 28: 479-488, 2004.

2 Reith JD, Goldblum JR, Lyles RH and Weiss SW: Extragastrointestinal (soft tissue) stromal tumors: an analysis of 48 cases with emphasis on histologic predictors of outcome. Mod Pathol 13: 577-585, 2000.

3 Fletcher CD, Berman JJ, Corless C, Gorstein F, Lasota J, Longley BJ, Miettinen M, O'Leary TJ, Remotti H, Rubin BP, Shmookler B, Sobin LH and Weiss SW: Diagnosis of gastrointestinal stromal tumors: A consensus approach. Hum Pathol 33: 459-465, 2002.

4 Zheng S, Chen LR, Wang HJ and Chen SZ: Analysis of mutation and expression of $c-K I T$ and PDGFR alpha gene in gastrointestinal stromal tumor. Hepatogastroenterology 54: 22852290, 2007.

5 Miettinen M and Lasota J: Gastrointestinal stromal tumors-definition, clinical, histological, immunohistochemical, and molecular genetic features and differential diagnosis. Virchows Arch 438: 1-12, 2001.

6 Agaimy A and Wunsch PH: Gastrointestinal stromal tumours: a regular origin in the muscularis propria, but an extremely diverse gross presentation. A review of 200 cases to critically reevaluate the concept of so-called extra-gastrointestinal stromal tumours. Langenbecks Arch Surg 391: 322-329, 2006.

7 Sakurai S, Hishima T, Takazawa Y, Sano T, Nakajima T, Saito $\mathrm{K}$, Morinaga $\mathrm{S}$ and Fukayama M: Gastrointestinal stromal tumors and KIT-positive mesenchymal cells in the omentum. Pathol Int 51: 524-531, 2001.

8 Llenas-Garcia J, Guerra-Vales JM, Moreno A, Ibarrola C, Castelbon FJ, Fernandez-Ruiz M, Meneu JC, Ballestin C and Moreno E: Primary extragastrointestinal stromal tumors in the omentum and mesentery: a clinicopathological and immunohistochemical study. Hepatogastroenterology 55: 1002-1005, 2008. 
9 Goh BK, Chow PK, Kesavan SM, Yap WM, Chung YF and Wong WK: A single-institution experience with eight CD117positive primary extragastrointestinal stromal tumors: critical appraisal and a comparison with their gastrointestinal counterparts. J Gastrointest Surg 13: 1094-1098, 2009.

10 Yamamoto H, Kojima A, Nagata S, Tomita Y, Takahashi S and Oda Y: KIT negative gastrointestinal stromal tumor of the abdominal soft tissue: a clinicopathologic and genetic study of 10 cases. Am J Surg Pathol 35: 1287-1295, 2011.

11 Zheng S, Huang KE, Tao DY and Pan YL: Gene mutations and prognostic factors analysis in extragastrointestinal stromal tumor of a Chinese three-center study. J Gastrointest Surg 15: 675-681, 2011.

12 Kim KH, Nelson SD, Kim DH, Choi KU, Kim SJ, Min KW, Jang KS, Paik SS, Oh YH, Chae SW, Sohn JH, Kim HJ, Cho YK, Kim BI, Park DI, Sohn CI, Oh S, Choi SH, Choi YJ, Woo HY, Park YL, Park SJ, Lee SH, Ryu S, Do SI, Kang G, Kim K, Cho YH and Pyo JS: Diagnostic relevance of overexpression of PKC-theta and DOG-1 and KIT/PDGFRA gene mutations in extragastrointestinal stromal tumors: a Korean six-centers study of 28 cases. Anticancer Res 32: 923-937, 2012.

13 Patnayak R, Jena A, Parthasarathy S, Prasad PD, Reddy MK, Chowhan AK, Rukamangadha $\mathrm{N}$ and Phaneendra BV: Primary extragastrointestinal stromal tumors: a clinicopathological and immunohistochemical study - a tertiary care center experience. Indian J Cancer 50: 41-45, 2013.

14 Iqbal N, Sharma A and Iqbal N: Clinicopathological and treatment analysis of 13 extragastrointestinal stromal tumors of mesentery and retroperitoneum. Ann Gastroenterol 28: 105-108, 2015.

15 Barros A, Linhares E, Valadao M, Goncalves R, Vilhena B, Gil $\mathrm{C}$ and Ramos C: Extragastrointestinal stromal tumors (EGIST): a series of case reports. Hepatogastroenterology 58: 865-868, 2011.

16 Vernuccio F, Taibbi A, Picone D, LA Grutta L, Midiri M, Lagalla $\mathrm{R}$, Lo Re G and Bartolotta TV: Imaging of gastrointestinal stromal tumors: From diagnosis to evaluation of therapeutic response. Anticancer Res 36: 2639-2648, 2016.

17 Hirota S, Isozaki K, Moriyama Y, Hashimoto K, Nishida T, Ishiguro S, Kawano K, Hanada M, Kurata A, Takeda M, Muhammad Tunio G, Matsuzawa Y, Kanakura Y, Shinomura Y, and Kitamura Y: Gain-of-function mutations of $c$-KIT in human gastrointestinal stromal tumors. Science 279: 577-580, 1998.
18 Rubin BP, Fletcher JA and Fletcher CD: Molecular insights into the histogenesis and pathogenesis of gastrointestinal stromal tumors. Int J Surg Pathol 8: 5-10, 2000.

19 Lux ML, Rubin BP, Biase TL, Chen CJ, Maclure T, Demetri G, Xiao S, Singer S, Fletcher $\mathrm{CD}$ and Fletcher JA: KIT extracellular and kinase domain mutations in gastrointestinal stromal tumors. Am J Pathol 156: 791-795, 2000.

20 Medeiros F, Corless CL, Duensing A, Hornick JL, Oliveira AM, Heinrich MC, Fletcher JA and Fletcher CD: KIT-negative gastrointestinal stromal tumors: proof of concept and therapeutic implications. Am J Surg Pathol 28: 889-894, 2004.

21 Miettinen $M$, Virolainen $M$ and Maarit Sarlomo R: Gastrointestinal stromal tumors - value of CD34 antigen in their identification and separation from true leiomyomas and schwannomas. Am J Surg Pathol 19: 207-216, 1995.

22 Heinrich MC, Corless CL, Duensing A, McGreevey L, Chen CJ, Joseph N, Singer S, Griffith DJ, Haley A, Town A, Demetri GD, Fletcher CD and Fletcher JA: PDGFRA activating mutations in gastrointestinal stromal tumors. Science 299: 708-710, 2003.

23 Lasota $\mathrm{J}$ and Miettinen M: KIT and PDGFRA mutations in gastrointestinal stromal tumors (GISTs). Semin Diagn Pathol 23: 91-102, 2006.

24 Miettinen M, Sobin LH and Lasota J: Gastrointestinal stromal tumors of the stomach: a clinicopathologic, immunohistochemical, and molecular genetic study of 1765 cases with long-term followup. Am J Surg Pathol 29: 52-68, 2005.

25 Corless CL, Schroeder A, Griffith D, Town A, McGreevey L, Harrell P, Shiraga S, Bainbridge T, Morich J and Heinrich MC: PDGFRA mutations in gastrointestinal stromal tumors: frequency, spectrum and in vitro sensitivity to imatinib. J Clin Oncol 23: 5357-5364, 2005.

26 Terada T: Primary multiple extragastrointestinal stromal tumors of the omentum with different mutations of $c$-KIT gene. World J Gastroenterol 14: 7256-7259, 2008.
Received January 21, 2018

Revised February 22, 2018

Accepted February 26, 2018 